D.O.I.: $10.3895 / \mathrm{S} 1808-04482011000200009$

\title{
MARKETING PLANNING AND ORGANIZATIONAL STRUCTURES
}

\section{PLANEJAMENTO DE MARKETING E ESTRUTURAS ORGANIZACIONAIS}

\author{
Luciano Augusto Toledo \\ Universidade Presbiteriana Mackenzie - SP - SP \\ Luciano@mackenzie.br
}

\begin{abstract}
This article is structured in the essay form, and consists of a review of the theoretical framework through a critical analysis of some aspects relevant to the issues, planning and marketing organizational structure. It is described and analyzed the formulation of corporate strategies, competitive and functional in the context of marketing planning. Finally, it held a discussion and appointment of some inherent to the subject matters addressed in this work.
\end{abstract}

Key-words: organizational structure; marketing planning; strategies.

\section{Introduction}

The constant and uncontrollable changes that occur in the contemporary business environment demand permanent adaptations and adjustments in productive and administrative products and processes, and those who do not attempt to adequate to the new environmental conditions will face difficulties to grow and survive (JOHNSON et al., 2010; NEFF, 2011; ROWLEY, 2010). Companies are exposed to drastic changes in managerial and cultural paradigms, and many are disoriented and pathless in the face of the situations prevalent in the external environment. In this technical-cultural revolution scenario, strategic planning and marketing planning stand out as guiding instruments for the improvement of corporation competitiveness, push forth the growth of the organization and articulate changes in organizational structures (TOLEDO; CAIGAWA et al., 2006). In this sense, all and any changes in configuration in an organizational structure may bring improvements. Thus, the aforementioned justifies a scientific study dealing with some of the specificities of the theoretical references that base the concepts of strategic and marketing planning in the scope of organizational structures.

\section{Work Method}

The paper is an essay, which is conceived by Medeiros (2000) as a methodological narrative on a subject and the offering of original conclusions reached after accurate examination of such 
subject, based on documented evidence. For the author, the essay is, by nature, "problematic rendering" and non-dogmatic, and in it, the author's critical spirit and newness, or better, originality, should prevail. As Severino (2000) ponders, in the essay the author is more free to defend a certain position, without having to sustain the rigorous and objective apparatus of empirical and bibliographical evidence. In fact, the essay does not dismiss the logical rigor and coherence of argumentation and, for this very reason, demands cultural information and intellectual maturity (COLLIS; HUSSEY, 2010; DEMO, 1995). The essay proposes to undertake a formal, discursive and conclusive analysis and unfolds into a logical and reflexive narrative on strategic and marketing planning, and the model of organizational structures.

\section{Theoretical Reference}

\subsection{Some aspects of marketing planning and organizational structures}

According to Toledo (2003), a characteristic of strategic strategies is to assure the accomplishment of the corporation's growth objectives over time, by evaluating the present and intended strategic business units and carrying out a strategic analysis for resource allocation. The aim of those strategies is to decide on the business transactions a corporation will undertake and the amount of resources necessary o maintain them. There are five possible growth strategies for a corporation, of which three are related to intensive growth (KOTLER; KELLER, 2006; ANSOFF, 1957), and are described bellow. Intensive growth strategies are aimed at identifying companies' present business growth opportunities which for the companies' present business and can be configured as, market penetration, market development, and product development. The integrated growth strategy is aimed at identifying growth opportunities in business transactions related to the present ones. They may try to acquire companies upstream or downstream, or try to accomplish horizontal integration through consolidations or takeovers. Finally, the corporation can choose a diversified growth strategy, where it tries to identify growth opportunities in businesses unrelated to the present ones (HOOLEY; SAUNDERS; PIERCY, 2005). The decision to invest in a corporation will depend on the structure of the industry analyzed, on a case-by-case basis. Porter (1998) defined five competitive forces that affect the attractiveness and competitiveness of a given industry. Those forces refer to the potential entrances, the sellers' and buyers' bargaining power, the threat of substitute products, and finally competition with other present companies. Hooley, Saunders and Piercy (2005) add that any diversified organization needs to find methods to appraise the balance among businesses in its portfolio and aid in resource allocation among them.

After defining the markets to be served by the organization, the corporation needs to conquer and maintain them. Porter (1998) theorizes on this position as the process for the search for 
a competitive or business strategy. This strategy can be reached in many ways. However, it is possible to synthesize them in two global propositions: leadership in costs and differentiation (PORTER, 1998). Competitive strategies reflect the organization's capacity to adjust in accordance with what has been identified in terms of its attractiveness and competitiveness. Besanko, Dranove and Shanley (2000) render relative those strategic positions by defining the concept of created value. While Porter (1998) argues that the best outcome is in the capacity to take advantage of the corporation's value chain to reduce costs or create relevant differentials for consumers, without admitting mixed situations. Another important point in the formulation of competitive strategies is the concern with maintaining a competitive edge. Competitive edges can be protected through isolation mechanisms that neutralize the competition's value creation sources (BESANKO; DRANOVE; SHANLEY, 2000). These mechanisms can be a barrier against imitations (legal restrictions such as patents and copyright, exclusive access to clients, scale economies in limited markets, and intangible barriers related to historical circumstances and social complexity), or advantages resulting from quick changes (learning curves, network externalities, the brand's reputation when consumers are not sure about the product's quality, etc.) (VALENTIM; GELINSKI, 2005).

Prahalad (2004) defends that its not enough for the corporation to simply carry out competitive positioning exercises. According to the author, companies should try to respond to the question of how to model their competencies in future scenarios. That is, instead of looking at past analysis, one must look, in a creative way, for new market opportunities, interactions with clients, and other relevant firms and markets. Gummesson (2005) proposes two phenomena that attempt to aid the understanding and formulation of the organization's competitive strategies, the systems' theory and the theory of transactional costs. In both cases, the author advocates that corporation's borders with clients and suppliers are not clear, but form relationships intertwined in an orderly way. The strategy, under the systemic point of view, argues that the corporation is in constant interaction with the environment and, therefore, all strategies must consider the client as an extension of this system. Complementing the aforementioned strategy models, the Delta Model reflects a description of the success of competitive strategies (TOLEDO; QUELOPANA; POLERO, 2005). The authors argue that this model explains and aids in the process of making strategic decisions, in the present global context. According to (HAX; MAJLUF, 1996), the Delta Model recognizes differentiation and cost leadership strategies - Best Product, but the paradigm of delivering the best product supercedes them. Additionally, according to these authors, this model foresees the strategic option of serving clients in the best way possible - Solutions for clients. This strategy allows the corporation to anticipate the clients' needs and increase its understanding and learning about them and, lastly, results in positive impacts upon the relationship. Finally, the model 
considers as an option that the corporation should extrapolate the organizational limits - System Lock-in. Instead of concentrating only on the product or the customer, the corporation considers all the elements of the system that contribute towards the creation of economic value. These elements appear as suppliers and other organizations, named complements, and are parts of the systems that supply the goods and services of the main organization (HAX; MAJLUF, 1996).

Functional strategies are decisions subordinate to business or competitive strategies. These decisions are made in connection with the corporation's functional activities and administrative processes, whether they are related to the final activities, or support areas such as marketing, people management, production, finances, $R \& D$, information technology, etc. (HOOLEY; SAUNDERS; PIERCY, 2005). Although these strategies are defined as a strategic level, the subordinate decisions that operationalize the search for competitive edge and growth can also be seen as action programs. This confusion results from the point-of-view adopted. At this hierarchical level, if the competitive strategy is taken as a reference, the subordinate decisions can be seen as actions to reach the objective established at the higher level. According the definition offered by Mintzberg (2002), where the programs are specific steps in actions necessary to reach the main objectives, these activities are part of the corporation's action program. The confusion also arises from the use of the terms "strategic plan" in the different functional areas, such as marketing, human resources, production and finances. These plans are operational and their outcome is the definition of action programs of each area, and they are subordinate to competitive strategies. One notes that the dimensions treated are totally distinguished from the corporation's strategic and corporate planning.

An organizational structure can be defined as the arrangement of people and designated tasks to reach the organization's objectives (FINK; JENKS; WILLITS, 1983). This structure is the outcome of a process of division of the authority established in the corporation, where activities are specified and communication flows are defined. It is through this program that companies carry out their strategies in order to reach their aims. Galbraith (2001) completes this thought by stating that the organizational structure is designed to maintain, over time, the corporation's strategic choices in coherence with the established organizational goals. Authors such as Vasconcellos and Hemsley (2002) consider that an organizational structure is comprised of three elements: authority subsystem, communication sub-system and activities sub-system, all of them managed within the clusters of people existing in the organizations. These specific clusters form units called departments. Such divisions allow the organizations' collaborators to be administered within this subsystems logic. Still according to the same authors, what defines departmentalization is the breadth of control, the hierarchical levels, the degree of decentralization, communications systems, and the corporation's degree of formalization (GHOSHAL; BARROS, 2004). The means of 
formalizing such structures is through organizational charts, memos and assignments. These divisions constitute end areas or support areas, such as data processing or accounting, or such as consultancies. Organizational structures can be classified into traditional. The first classification is more favorable in organizations whose activities are more predictable, and whose market environment is at a relatively stable stage. In many cases, traditional structures don't resist the outer environment's impacts. Due to this complexity, some organizations have begun developing more flexible structures (VASCONCELLOS; HEMSLEY, 2002). With the increase in the environmental turbulence, traditional models have become bureaucratic obstacles tending towards organizational stagnation and rigidity in the capacity to respond to these changes. The metaphor of the mechanist, or, analogously, traditional organization, does not support the corporation's new needs. Other metaphors then appear, such as those based on the organic concept that has adapted to the dynamic model of survival (MORGAN, 1999), or the flexible, collaborative model, based on competencies and with horizontal communication.

Organizational structures can be composed in many ways, depending on the companies' strategies, from classical functional structures, to the forming of cooperation networks among companies within a value system. According to Ito and Rose (2004), structures can be characterized as: functional ones split into divisions, diversification by conglomerates, diversification based on competencies, keiretsus, and alliance networks, where: Functional structures are more efficient when companies are small and have few product lines; Structures by division are clusters based on markets or products and, within each division, departments are established around the product or market at hand; Diversification by conglomerates is an organization characterized by the use of expansion strategies in the search for growth opportunities in connection to attractive markets. This form of organization behaves like an umbrella for businesses or other companies, also called strategic business units, which are successively purchased or sold, based on financial criteria; Diversification based on competencies is similar to the former, but it is more directed towards an expansion constructed upon internal competencies such as abilities, technologies, organizational learning, etc. In this form of structure, long-term actions are more valued, while in the first form one aims at equating investments and financial return; Organizations based on keiretsu have originated from family-based organizations called zaibatsu. The difference between the two is that the first is a modern conception, not based on personal ties of kinship. In keiretsu, companies create a bond of dependency and functional hierarchy around cooperation and assistance in the same way as members of a large traditional family. The alliance networks, differently from keiretsu, are not formed by bonds of friendship and loyalty among its peers. These networks are the consequences of the adaptive necessities for the realization of complex competitive strategies that can only be carried out through joint action among organizations. They can take on several shapes, from joint ventures 
and cooperation contracts to the total integration of operations, the aim of which is to completely control a certain market (ITO; ROSE, 2004).

The functions of marketing as an instrument to facilitate exchanges take place through a set of specialized activities, which are carried out in the scope of marketing administration. According to the conception of Kotler and Keller (2006), marketing administration or management is the process of executing the conception, the determining of the price, the promotion and distribution of ideas, goods and services to create transactions that fulfil the individual and organizational objectives. Toledo and Fortes (1989), in describing the managerial dimension of marketing, that is, marketing administration, point out that some aspects should be taken into consideration. The first one of them refers to the administrative process itself. Marketing, like any other functional area, carries out four classic functions that comprise the administrative process: planning, organization, direction (coordination) and control.

An important aspect in marketing compound management, pertinent to the marketing planning process, refers to the issue of deciding upon the allocation of the marketing budget, among several products, channels, and sales promotion instruments (WESTWOOD, 2005). Campomar (1984) suggests a systemic representation of the operational process, which allows for obtaining a dynamic idea of the flows that determine the exchange system, in addition to evidencing the uncontrollable external variables, which can provoke favorable or unfavorable impacts upon the corporation's relationships with its respective markets. Under a strategic perspective, the marketing system requires an examination of the market in terms of tendencies, events and market demands, as well as the opportunities offered in the long term. In this case, the analysis work is prospective, and its objective is to raise and appraise market segments to be profitably exploited by the corporation, in consonance with its resources and objectives. As a result of the analysis of the marketing opportunities and the assessment of the corporation's competitive potential, in comparison with the competition, it will be enabled to decide on the position it will take in the market, in relation to competitors, so as to form a differentiated image in terms of product, price, promotion and area of delivery.

At the strategic level of functional marketing structures, two closely related concepts stand out: market segmentation and positioning (HOOLEY; SAUNDERS; PIERCY, 2005). The concept of segmentation points to a process that develops from a phase characterized as the partition of the target-market, identified in marketing texts as segmentation. This stage of the strategic and competitive marketing process refers to raising the segmentation variables and designing the profile of the market segments that could be reached by specific marketing compounds.

In a second stage, there is a priority decision to be made; in this stage one seeks to accomplish a strategic choice of segments, in order to obtain a competitive edge. The process 
culminates with the positioning stage. Thus, the segmentation and positioning processes constitute the core of the corporation's strategic marketing and the essence to achieve greater competitiveness (HOOLEY; SAUNDERS; PIERCY, 2005). It is in the context of this strategic dimension that market segmentation proves to be of importance for marketing planning, particularly in formulating and implanting marketing strategies for specific markets (PETER; DONNELLY, 2002; MCDONALD; DUNBAR 1995).

Under the Marketing Planning aspect Harrison (2005) suggests that it can be conceived as a sequence of decisions in time. Alternatively, as a process that involves a set of actions aimed at pushing a corporation towards fulfilling its short-term goals and long-term objectives. Furthermore, according to the author referred, strategies present themselves in all organizations, both the simplest as the largest and most complex, but they may vary in terms of the degree of formalism with which they are formulated and implanted. In some companies, especially those which operate in rapidly changing environments, or in small-scale organizations, strategies are not described as "planned", according to the formal conception of the term. In addition to the degree of formality, strategies can be considered in terms of being deliberate or emergent (HAX; MAJLUF, 1996). In deliberate strategy, managers plan to follow a certain predefined and intentional course of action. An emergent strategy means that it is not necessarily planned or intentional, but the result of patterns and consistencies observed in the past, through a trial and error process. These last two concepts constitute the limits of the different combinations that form the basis for a typology that characterizes strategy formulation processes. Strategy formulation, conceived as a process of planning strategies, or, in the broadest sense, the process of strategic planing, can be dismembered into three levels: corporate, corporation-wide or pertaining the strategic business unit (SBU), and functional (KOTLER; KELLER, 2006).

At the corporate level, the formulation of the strategy (strategic planning) refers to the definition, assessment and selection of business areas in which the organization will compete, and the emphasis that should be placed on each area (TOLEDO; FREIRE; LUIS, 2006). At this level, the main issue is the allocation of resources among the organization's business areas, according to the criteria of attractiveness and competitive position of each of the areas, whereby the strategies are predominantly aimed towards the growth and permanence (survival) of the organization (TOLEDO; FREIRE; LUIS, 2006). Strategic formulation at the second level - of the corporation or the strategic business area - is related to the effective use of the resources and refers to the direction towards which the corporation will aim the business scope. At this level, the so-called competitive strategies prevail. Thus, the single business strategy refers to the way in which the organization will compete in the chosen markets (TOLEDO; FREIRE; LUIS, 2006).

In medium-scale companies with one single SBU, strategic marketing planning and 
operational marketing planning can be developed as a single process (STEVENS et al., 2001), and, in smaller organizations, the planning process incorporates the three levels simultaneously. Harrison (2005) adds to this, stating that when dealing with strategies in the scope of the corporation, decisions are reached at the highest levels of the organization, although the people at that level may receive information from managers at lower levels. If a certain organization has only one business unit, the first and second level decisions are made by the same people. In organizations with multiple businesses, decisions at the business unit level are made by the highest-level executives in the unit; at the functional-area level decisions are made by the respective managers. That an organization implanting a marketing strategy presupposes the existence of a structure to operationalize activities. It is by means of coordination of the people involved in the structure that the marketing compound decisions take place (CAMPOMAR, 1984).

Additionally, marketing structures are subordinate to the organization's general organizational structures and, accordingly, are aligned with the existing competitive and corporate strategies (STEVENS et al., 2001). This reasoning leads one to believe that the execution of marketing activities may be diluted in other departments, such as sales, production, institutional communication, R \& D, finances, etc. The marketing managers lack, many times, the power to alter the existing structures (TOLEDO; FREIRE; LUIS, 2006). The marketing area's structure may take on different shapes, depending upon the emphasis given to the type of coordination and control intended by the organization. Boyd and Massy (1972) classify marketing structures into four different groups: functional, products administration, markets administration and general administration. McDaniel (1979) describes the existence of some structures: product based, functional, geographically divided, and the matrix-based form. Davis (1981) classifies four ways of organizing the marketing structure: functional, product, market and mixed (product and market) (TOLEDO; FREIRE; LUIS, 2006).

Among the ways of organizing the marketing structure, the most traditional are the functional structure, product structure and market structure. The first is departmentalized by activities (sales, promotion, marketing research, marketing planning). There is an executive responsible for the organization's total marketing effort and those responsible for each one of the activities are subordinate to it (OLIVEIRA; CAMPOMAR, 2006). The second case occurs when the organization has a varied production, that is, there are several products and brands. As the complexity or resource administration increases, for each one of these products, the organization finds itself compelled to delegate a product manager for markets to each group. This happens when the organization offers its products to a set of highly diversified markets. In this case, the organizational structure should allow specialization per market, with areas aimed at each one of them (OLIVEIRA; CAMPOMAR, 2006). According to Achrol (1991), in spite of the changes in the 
marketing environment during the end of the last century, many times, organizational structures are still developed on functional bases. The author advocates that, in a dynamic environment, those forms should be revised. Ruekert, Walker Jr and Roering (1985) have developed a contingencybased approach to restructure these activities within the several environmental settings and the proposed organizational objectives. According to the authors referred, structures can take on :

- bureaucratic form: structures are rigid, formalized and loosely integrated;

- organic form: structures are decentralized, non-formalized and based on specialized groups;

- transactional form: structures take into consideration internal organizational aspects and the employment of outside organization companies;

- relational form: the structures are similar to the transactional ones.

Organizational structures are moving towards an ever more fluid situation, based on hybrid structures that can take on different designs (DAY, 1999). Also, marketing activities are less and less concentrated in departments or identified with specific employees in the organization (GUMMESSON, 2005). In spite of the present paradigm, which places great importance on marketing philosophies within companies' corporate and competitive strategies, organizations' structures tend to dissolve the existing marketing departments. Many of the traditional marketing activities, such as account and customer administration, product development, price definition and distribution, are being moved to other areas of the strategic business units. Functions related to marketing information systems are sometimes included in the marketing assignments, sometimes excluded, and, lastly, most companies are reducing their marketing areas to brand management and communication areas (WEBSTER JR; MALTER; GANESAN, 2005).

Webster Jr, Malter and Ganesan (2005) list, as the main causes of changes in organizational structures: The pressure for short-term financial results (purchasing business units well-placed in markets, instead of developing new businesses); The difficulties of the marketing areas is to find the way to measure their productivity; the changes in power and control within value systems; the difficulty present marketing structures find in moving towards and efficient administration of client relationships; the deflection of organizational resources from marketing to sales; the strengthening of a client and value-based orientation in management structures, so that such issues no longer appear as belonging to the marketing area.

\section{Relationship among Marketing Planning and Organizational Structures}

The dilemma between the need to structure planning and the tendency to deal with more and more complex and organizational structures suggests the creation of an organizational formalization instrument that will help identify those responsible for carrying out marketing 
planning, without the need for a marketing department. An alternative proposed for this end is the formulation of marketing planning through its structural context, in connection with its most relevant activities, where procedures and rules can be assessed and executed (JOHN; MARTINS, 1984). This context can be identified by a matrix that associates activities related to planning, such as collaborators or areas responsible for its implantation and control. There are several instruments for formalizing activities and responsibilities that can help the organization formalize its administrative activities, independent from traditional organization charts, and which are useful in increasing the organizational formalizing of marketing planning (VASCONCELLOS; HEMSLEY, 2002). Among them, one can point out the functional organizational chart and the ARF administrative flow chart (BARNES et al., 1970). Where the first includes a set of roles or positions aligned in columns and a set of responsibilities and authorities in lines. The cells formed in this matrix reflect different persons' situation in regards to the activities, which are: the individual responsible for the execution and/or decision upon the activity, the individual who must be consulted before and after the decision and/or execution of the activity, the individual who must be informed after the decision and/or execution of the activity, among other possibilities. The second instrument is similar to the first, but employs administrative procedures existing during an administrative action, that is, the activities are placed according to the order of their execution on the columns and those responsible for the decision, retention, direction, delegation and action are listed on the lines.

As an example for the application of these instruments in marketing planning, the AFC lines could be determined in accordance with the description of the planning activities, such as segment identification, target-market choices and marketing positioning. As for the columns, they could adequate to the prevailing structural organizations in the companies, such as sales, finances and communications departments, etc., or even include external activities such as the employment of research institutes and publicity agencies.

One of the questions raised here is directly linked to corporation planning and the role of marketing administration. Lambin (2000) firmly believes that to remain competitive it is necessary to plan and, accordingly, Kotler and Keller (2006) state that marketing has the function of leading the process of staying competitive. During the analysis of the available bibliographical references pertaining to the development of the theme, a consensus was observed between professional and entrepreneurial theorists: That it is necessary to redirect planning techniques and management processes in order to encourage the marketing strategy; the realization of consistent forecasts and adjustments of the corporate resources to new market opportunities. In spite of the questions as to the relevance of planning, for Lambin (2000), the benefits of such a process are indisputable. Still according to the author, strategic and marketing planning both allow for assessing the corporation's 
position in the market, identifying favorable and unfavorable situations coming form the external environment, assessing ones strengths and weaknesses, and concluding therefrom on present and future threats and opportunities. The author also recalls that planning favors the establishment of goals, objectives, priorities and strategies, in addition to leading to collaborators (employees) effectively committing to any change in the corporation.

Another question concerns the possibility of planning retarding actions and causing some administrators to feel curtailed, and, consciously or unconsciously, not allowing self-initiative and an enterprising and innovative spirit to surface. Lambin (2000) suggests not a criticism of planning itself, but a limitation inherent to some organizations that makes the process o planning difficult. This limitation is related to the fact that some companies find it impossible to build a marketing information system that makes it possible to constantly monitor the movements of the competition, the market and the other forces and entities in the external environment. Still according to the author, a marketing information system may be an indispensable requirement for the corporation's management, in seeking competitive edges.

One characteristic of companies that employ formalized operational marketing planning is that they do this in the form of a marketing plan (CAMPOMAR, 1984; LAMBIN, 2000; KOTLER; KELLER, 2006). As proposed by Campomar (1983), the activities inherent to a marketing plan include carrying out an analysis of the situation, determining the objectives, developing the strategies, deciding upon action programs for the components of the marketing compound and preparing supporting financial displays (budgets and profit and loss projections) (CAMPOMAR, 1984; LAMBIN, 2000; KOTLER; KELLER, 2006). The plan, as the advocated by the author, is the formal document, which substantiates the mental process of marketing planning. In this context, an objection is raised against the rigidity and the authoritarian and formal conception of the plan and planning process. Thus, a corporation, when putting a plan into action, is risking consolidating a bureaucratic attitude and behavior, which, by its very nature, is the opposite of the desirable flexibility necessary to deal with unstable environments (CAMPOMAR, 1984; LAMBIN, 2000; KOTLER; KELLER, 2006).

The importance of planning is a fact, whether in the process of re-structuring organizational hierarchies, or in the creation of new products and services, or even in deciding on new ways of pricing the products offered. As refers to adopting new organizational configurations in order to remain competitive, companies must plan, and the formalizing of planning may or may not result in a marketing plan (CAMPOMAR, 1984; LAMBIN, 2000; KOTLER; KELLER, 2006). As refers to the use of hierarchies by organizations, Hooley, Saunders and Piercy (2005), recall that innovation may be uncertain, that is, it would not be possible without management. However, the authors referred point out that the more and organization looks for innovation, the more experience it will 
accumulate, and, consequently, it will be more able to manage processes and remain competitive (CAMPOMAR, 1984; LAMBIN, 2000; KOTLER; KELLER, 2006).

\section{Final Considerations}

The strategic process in an organization is a permanent process of adjustment and adaptation of its objectives and resources, competencies and capacities, to the opportunities offered by the changing business environment. Planning, at the strategic, tactical, and operational levels, shows itself as a mechanism that allows for the adjustment, aimed at gaining sustainable competitive edges, and consequently attaining growth and profitability, in an environment characterized by uncontrollable and unforeseen changes. In such cases, marketing is raised to the strategic level. It is timely to point out that strategic planning and marketing planning are key parts in the context of the management process at its several hierarchical levels. In that respect, marketing planning, in organizations geared towards clients or markets, plays a central role in the system, as an inseparable instrument in the process of formulating and implanting competitive and growth strategies and as an agent that facilitates and maintains upcoming organizational changes, even in structures that no longer have a functional marketing department.

The article did propose to analyze all the chains of thought in the discussion on strategy, organizational structures and marketing planning. The intention was to bring to light a discussion around the relationship between these concepts, and, specifically, between them. The hope is that the insights generated throughout this study can contribute to the development of marketing and of future studies in the area. The aim was to clear up the differences between the several strategic levels in the formulating of corporate, competitive and functional strategies, in addition to situating the marketing planning process in the organizational structure. Also analyzed were the effects of these strategies in the companies' structural arrangements. In this way, the fostering of organizational structures around classic clusters, like the functional one, or aimed at innovation, may go beyond the borders of companies' properties.

Permeating the discussion above, the article "brought to light" some aspects of the function and activities of marketing that are related to the activities of marketing planning and organizational structure. Finally, the text brought forth a direct reflection about the relationship between marketing planning, and organizational strategies and structures, and briefly described the ways of enhancing its execution in structures.

The considerations made upon the authors were based on the interpretation of the sources and evidences consulted, and are, therefore, guided by the conception of the researcher and, occasionally, subject to bias, in some statements, and, since this research has been of an exploratory nature, the results mentioned should not be generalized. Since it is an academic work structured as 
an essay, the intention was not to carry out any analytical descriptive or illustrative exploratory research, in connection with the case-study method. The essay has been a theoretical and provocative contribution, the intention of which is to waken the theoretical and investigative spirit of future researchers. For a better contribution to the state of the art in administration, it is suggested that single-case or multi-case studies be carried out, in order to validate future hypothesis the essay may have instigated in the reader.

\section{Resumo}

$O$ artigo foi estruturado sob a modalidade de ensaio, e compõe-se de uma revisão do referencial teórico, mediante uma análise crítica de alguns aspectos pertinentes aos temas, Planejamento de marketing e Estrutura organizacional. É descrito e analisado a formulação de estratégias corporativas, competitivas e funcionais no âmbito do planejamento de marketing. Por fim, é realizada uma reflexão e apontamento de algumas questões inerentes ao tema abordado neste trabalho.

Palavras-Chaves: estrutura organizacional; planejamento de marketing; estratégias.

\section{Referencies}

ACHROL, R. S. Evolution of the marketing organization: new forms for turbulent environments. Journal of marketing. 55, p. 77-93, October 1991.

AMA - AMERICAN MARKETING ASSOCIATION. Marketing glossary dictionary. Disponível em: $<$ http://www.marketingpower.com/live/mg-dictionary.php?>. Acesso em: 24 jan. 2006.

BARNES, M. C. et al. Corporation organization - theory and practice. London: Allen and Unwin, 1970.

BESANKO, D.; DRANOVE, D.; SHANLEY, M. Economics of strategy. 2 ed. New York: Wiley, 2000.

BOYD JUNIOR, H. W.; MASSY, W. F. Marketing management. New York: Harcourt Brace Jovanovich, 1972.

CAMPOMAR, M. O Sistema de marketing. Revista Marketing. São Paulo, 1984.

COLLIS, J.; HUSSEY, R. Business research: a practical guide for undergraduate and postgraduate students. Palgrave Macmillan, 2010.

DAVIS, K. R. Marketing management. 4. ed. New York: Wiley, 1981.

DAY, George. Aligning organizational structure to the market. Business Strategy Review. 10 (3), p. 33-46, 1999. cross'ref

DEMO, P. Metodologia cientifica em ciências sociais. Atlas, 1995.

FERRELL, O. C.; HARTLINE, M. D. Estratégia de marketing. Thomson, Brasil, 2005.

FINK, S.; JENKS, R. S.; WILLITS, R. D. Designing and managing organizations. Homewood: Irwin, 1983.

GALBRAITH, J. R. The essential galbraith. Mariner Books: Addison-Wesley, 2001.

GHOSHAL, S.; BARROS, B. T. Estrategia e gestão empresarial: construindo empresas brasileiras de sucesso. CAMPUS, 2004.

GREINER, L. Evolution and revolution as organizations grow. Harvard business review. p. 55-67, may/jun 1998. 
GUMMESSON, E. Marketing de relacionamento total. 2 ed. Porto Alegre: Bookman, 2005.

HARRISON, J. S. Administração estratégica de recursos e relacionamentos. Bookman, Porto Alegre, 2005.

HAX, N. S. e MAJLUF, A. C. The strategy concept and process: a pragmatic approach. Prentice Hall: 2nd edition, 1996.

HOOLEY, G. J., SAUNDERS, J. A. e PIERCY, N. F. Estratégia de marketing e posicionamento competitivo. Pearson- Prentice Hall: São Paulo, 2005.

ITO, K.; ROSE, E. L. An emerging structure of corporations. The Multinational Business Review. 12 (3), p. 63- 83, Winter 2004-2005.

cross'

JOHN, G.; MARTIN, J.. Effects of organizational structure of marketing planning on credibility and utilization of plan output. Journal of Marketing Research. XXI, p. 170-183, May 1984.

JOHNSON, L. et al. 2010 Horizon report. The New Media Consortium, 2010.

KOTLER, P. Administração de marketing: a edição do novo milênio. São Paulo: Prentice Hall, 2002.

KOTLER, P.; KELLER, K. L. Administração de marketing. São Paulo: Prentice Hall, 2006.

LAMBIN, J. J. Marketing estratégico. McGraw Hill: Lisboa, 2000.

MCCARTHY, E. J. Basic Marketing - A Global Managerial Approach. USA: McGraw-Hill, 1996.

MCDANIEL JR, C. Marketing: an integrated approach. New York: Harper \& Row, 1979.

MCDONALD, M.; DUNBAR, I. Market segmentation: a step-by-step approach to creating profitable market segments. London: Macmillan Business, 1995.

MEDEIROS, J. B. Redação científica: a prática de fichamentos, resumos, resenhas. 2a. ed. São Paulo: Atlas, 2000.

MINTZBERG, H. The strategy process: Concepts, Context, Cases. Prentice Hall, 4th Edition, 2002.

MORGAN, G. Imagin-I-Zacion (Management (Granica)). Spain, Ediciones Granica, S.A., January, 1999.

NARVER, J. C. e SLATER, S. F. The effect of a market orientation on business profitability, Journal of Markeing, Outubro, 1990.

NEFF, J. P\&G e-commerce chief sees blurring of sales, marketing. Advertising Age, v. 82, n. 15, p. 8, 2011.

OLIVEIRA, B.; CAMPOMAR, M. C. O Processo de Posicionamento Competitivo em Marketing. II Encontro de Marketing EMA da ANPAD, p. 1-13, 2006.

PETER, J. P.; DONNELLY, J. H. Preface to marketing management with power web. McGraw-Hill/Irwin, 2002.

PORTER, M. E. Competitive advantage: creating and sustaining superior performance (Hardcover). Free Press; 1st Free P edition (June 1), 1998.

PRAHALAD, C. K; The future of competition: Co-creating unique value with customers (Hardcover). Harvard Business School Press : February 18, 2004..

ROWLEY, J. Information marketing. Ashgate Publishing, 2010.

RUEKERT, R. W; WALKER JR, O. C; ROERING, K. The organization of marketing activities: A contigency theory of structure and performance. Journal of marketing. 49, p. 13-25, Winter 1985.

SEVERINO, A. J. Metodologia do trabalho científico. São Paulo: Cortez, 2000.

STEVENS, R. et al. Planejamento de marketing, Makron Books, São Paulo, 2001. 
TOLEDO, G. L. Relações públicas e marketing: Um Conceito Tridimensional. Anais do $18^{\circ}$ EN-ANPAD, Encontro Nacional da Associação Nacional de Programas de Pós-Graduação em Administração, Curitiba, setembro, 1994.

TOLEDO, G. L.; FORTES, W. G. Relações públicas e marketing: uma abordagem estratégica. Revista de Administração, São Paulo, v. 24, n. 3, p. 1-10, jul./set. 1989.

TOLEDO, G. L; QUElOPANA, E. M; POLERO, A. C. Diferentes estrategias para el éxito dentro de un holding latino americano. Estudio del actual líder en I+D+I. Reunião anual da associação nacional de programas de pós-graduação em administração, 2005. Anais... Brasilia, 2005.

TOLEDO, L. A.; CAIGAWA, S. M.; ROCHA, T. J. Reflexőes estratégicas sobre o composto promocional de marketing no contexto da internet. Um estudo exploratório junto a uma instituiçăo financeira. Revista de Administração Contemporânea, v. 10, n. jan/mar, p. 117-138, 2006.

TOLEDO, L. A.; FREIRE, C.; LUIS, D. E. F. Planejamento estratégico de marketing no âmbito do desenvolvimento organizacional. IX SEMEAD, p. 1-17, 2006.

VALENTIM, M. L. P.; GELINSKI, J. V. V. Knowledge management as part of the organizational competitive intelligence process. (Portuguese). Informacao Sociedade Estudos, v. 15, n. 2, p. 1-12, 2005.

VASCONCELLOS, E.; HEMSLEY, J. R. Estruturas das organizações. São Paulo: Thomson, 2002.

WEBSTER JR, F. E; MALTER, A. J; GANESAN, S. The decline and dispersion of marketing competence. MIT Sloan management review. 46 (4), p. 35-43, Summer 2005.

WESTWOOD, J. The marketing plan workbook (the sunday times business enterprise guide series). New York: Kogan Page, May 31, 2005.

\section{Dados do autor:}

Nome completo: Luciano Augusto Toledo

Filiação institucional: Mackenzie

Departamento: CCSA

Função ou cargo ocupado: Professor Adjunto

Endereço completo para correspondência (bairro, cidade, estado, país e CEP): Rua Diana 573 ap 310 Perdizes SP

Telefones para contato: 1192008067

e-mail:Luciano@mackenzie.br

Enviado em: 06/02/2010

Aprovado em: 20/06/2010 